\title{
Internationalization Of R\&D Activities: The Case Of Swiss MNEs
}

Philippe Gugler, University of Fribourg, Switzerland, World Trade Institute, NCCR Trade, Switzerland Julie Michel, University of Fribourg, Switzerland

\begin{abstract}
The roles of foreign research and development $(R \& D)$ activities, as well as the consequences of the internationalization of $R \& D$ for the domestic firms' specific advantages and the home country's specific advantages, are developed in this paper. Although it is now widely acknowledged that technological activities are becoming more internationally dispersed, theories on the implications of foreign $R \& D$ activities on home economies are still scarce. This research brings useful theoretical contributions and evidence to fill this gap. The hypotheses on the motivations for foreign $R \& D$ are also tested through an empirical investigation. The data includes 39,281 patents published by Swiss multinational enterprises (MNEs) at the European Patent Office (EPO) from December 1978 to September 2006 and 6,620 patent citations. The patent analysis is complemented by a survey involving 35 major Swiss MNEs. The results show that MNEs perform an increasing share of their $R \& D$ activities abroad, concentrated in a few developed countries. Further, MNEs invest and will continue to invest strongly in China and in Asian countries, as well as in developing countries. Supporting local customers and local market is the prevalent type of foreign $R \& D$. Yet, the access to foreign science and technology is becoming increasingly important in all host regions. Knowledge flows within the organization of the firm, suggesting that $R \& D$ centres are interconnected. Moreover, domestic firms become more competitive through their access to the host country's specific advantages and spend more resources, especially in the country of origin, the basis of their first competitive advantage.
\end{abstract}

Keywords: Multinational enterprises; Innovation; R\&D; Home countries

\section{INTRODUCTION}

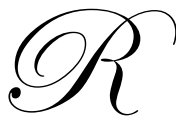

$\& D$ is one of the main sources for innovation and, for this reason, plays a part in determining the competitiveness and the growth of a national economy (Romer, 1990; Trajtenberg, 1990; Lichtenberg, 1992; Aghion and Howitt, 1992). R\&D is thus a priority in national policy on growth. It implies high-value activities with well-paid jobs. In order to sustain the capacity of innovation, policies and managers need to take into consideration the new developments in $R \& D$ strategies. First, innovative activities are becoming increasingly internationalized (UNCTAD, 2005; OECD, 2008a). Although some R\&D activities have been undertaken abroad for a long time (for instance, IBM has maintained a research laboratory in Switzerland since 1956), this trend was accelerated in the 1990s. According to the United Nations Conference on Trade and Development (UNCTAD, 2005, p. 125), between 1993 and 2002, R\&D expenditure of foreign affiliates worldwide had more than doubled, from 29 billion dollars to 67 billion dollars (or 16 percent of global business R\&D). This growth was more than twice as fast as that of global R\&D spending by enterprises (growth of 49 percent over the same period, UNCTAD, 2005, p. 125). A study by Booz \& Company, on the 1,000 public corporations worldwide that spend the most on research, found that in 2007, companies spent an average of 55 percent of their innovation dollars outside their home country (Booz \& Company, 2008). However, studies on the implications of foreign R\&D activities on home economies are still scarce and data on foreign $R \& D$ are limited. The effects of the internationalization thus need to be analysed, as it is important to understand the role of the international linkages of geographically dispersed $\mathrm{R} \& \mathrm{D}$ in the competitiveness of the multinational enterprises (MNEs) and domestic companies. Secondly, there has been a change in the localisation of foreign R\&D activities. Even if developed 
countries, notably the United States (US) and the United Kingdom, are the main destination for R\&D, emerging countries are becoming new partners in innovative activities. For instance, R\&D expenditures of US companies in China rose from 35 million dollars in 1995 (0.24 percent of total US foreign subsidiaries) to 565 million in 2003 (2.53 percent, United States Department of Commerce, 2008). It is essential to know what the role of R\&D is in these new locations to determine whether these countries are competing with developed countries in the attraction of R\&D investment. Thirdly, the motives of foreign R\&D are evolving. Until the 1980 s, the main role of R\&D abroad was to adapt products to market conditions (Hegde and Hicks, 2008). The internationalization of R\&D was thus a consequence of the globalisation of production activities and sales. Since the 1990s, MNEs have been investing in R\&D abroad to gain access to superior knowledge (Cantwell, 1995; Dunning and Narula, 1995). These new developments in R\&D strategies are analysed in this paper from the perspective of home countries.

Switzerland has been chosen for this investigation, as it is a major competitive and innovative country. It ranks second in the Global Competitiveness Index 2008-2009; first in company spending on R\&D; third in innovation capacity (World Economic Forum, 2008); fifth in R\&D intensity (share of gross domestic expenditure on $\mathrm{R} \& \mathrm{D}$ relative to gross domestic product), with a rate of 2.9 percent in 2004 (OECD, 2008b); and second in the triadic patent families per million population (OECD, 2007a). Switzerland is hence an innovation-driven economy with unique values in advanced skills and infrastructure. Secondly, the Swiss economy is significantly internationalised. It ranked fourth in the outward foreign direct investment (FDI) index in 2007 (UNCTAD, 2008). The total stock of Swiss FDI abroad has more than tripled since the second half of the 1990s, reaching 632 billion Swiss francs in 2006, up from 164 billion in 1995 (Swiss National Bank, 2007). This internationalisation of the Swiss economy is substantial as the outward stock in Swiss FDI constituted 144.1 percent of national gross domestic product (GDP) in 2006, whereas the average ratio in the European Union was 44.9 percent and in developed economies, 30.7 percent (UNCTAD, 2007). Finally, Switzerland reports the highest internationalisation of R\&D ratio in the OECD Activities of Foreign Affiliates (AFA) database (OECD, 2007b, p. 162).

The first part of this paper analyses, from a theoretical point of view, the motivations for the internationalisation of R\&D activities and the consequences for the domestic firms' specific advantages, as well as the home country's specific advantages. In the second part of this paper, the hypotheses on the motivations and impacts of foreign R\&D are tested through an empirical investigation. The data include 39,281 patents and 6,620 patent citations published by the European Patent Office (EPO) from December 1978 to September 2006. The 71 MNEs included in the data set have their headquarters in Switzerland and are the most innovative firms according to patent applications. This analysis is complemented in the third part of the paper by a survey involving 35 major Swiss MNEs.

The results are of great value for managers and politicians. Indeed, the analysis can be applied to other countries with an economy driven by innovation and whose companies have internationalised R\&D to a great extent, such as the United Kingdom, Sweden, and the US. Furthermore, the results identify points that should be taken into consideration by managers when planning their R\&D activities, which are the most valuable input for competitive advantages.

\section{THEORETICAL FOUNDATIONS OF FOREIGN R\&D ACTIVITIES}

\section{R\&D Motivations}

In the late 1970s, R\&D in MNEs received little attention from scholars as MNEs were supposed to undertake technological activities, mainly in the home country (see the traditional product cycle theory, Vernon, 1966; Cantwell et al., 2004, p. 58). This centralisation occurred because R\&D is one of the most strategic, and therefore sensitive, activities of firms. Firms therefore prefer to undertake these activities close to their headquarters, which closely monitors and controls them (Caves, 1996, p. 164). Furthermore, in centralising their R\&D at home, firms limit the risk of imitation and the leakage of information. For these reasons, R\&D activities have been largely performed at home (Patel and Pavitt, 1999). However, "An ethnocentric strategy to keep $R \& D$ in the home country may stop firms from achieving their optimum international knowledge position" (Kotabe et al. 2007, p. 275). MNEs benefit from the internationalisation of $\mathrm{R} \& \mathrm{D}$ as the geographical dispersion of innovations facilitates the technological development of the firm and influences its productivity (Branstetter, 2000; Van Pottelsberghe de la 
Potterie and Lichtenberg, 2001; Kotabe et al., 2007). It is now widely acknowledged that technological activity is becoming more internationally dispersed and that the international linkages of geographically dispersed R\&D are playing an ever more important role in the competitiveness of the foreign and domestic companies (Cantwell et al., 2004, p. 58). According to the theory of international business, the competitive strength of the MNE is improved through its access to specific assets in host countries, which are complementary to the assets the MNE already owns and which are not readily available in the country of origin (Dunning, 1977, 1988, 1993, 2000, 2001 and Dunning and Lundan, 2008). In the case of R\&D activities, specific assets of host countries relate to the possession of specific skills, specific knowledge or technological capacities that remain, to some extent, localised and cannot be transferred easily across borders due to the tacitness nature of new knowledge (Jaffee et al., 1993; Buckley and Carter, 2004; Inkpen, 2008). Thus, a new important source of competitive advantage is the capacity of foreign subsidiaries to create innovations based on host country's technological competences (Cantwell, 1995).

The trend towards the internationalization of R\&D became a widespread phenomenon in the 1990s. The notable theories on the role of foreign $R \& D$ have therefore notably emerged since this time, with the pioneer works of Kuemmerle (1997, 1999), Dunning and Narula (1995), Florida (1997) and Cantwell and Janne (1999). First, MNEs conduct R\&D abroad in order to win market share in unfamiliar countries. In this situation, foreign R\&D adapts products of processes to the characteristics of host countries, which may differ from those of the country of origin. Thus, research activities abroad aim to improve the products according to local tastes, needs, levels of education, technical standards or regulations. For instance, Nestlé, Switzerland, opened an R\&D centre in Singapore in 1982 to ensure that products comply with Asian taste preferences. Secondly, companies set up foreign operations in $R \& D$ to reduce costs, particularly of development activities. For example, many pharmaceutical companies transform drugs into tablets or capsules in countries where costs are lower. Thirdly, the country of origin of a firm may lack skilled manpower. The shortage of adequately qualified engineers in the US became apparent when the annual H1B visa quota (allowing US employers to temporarily employ foreign workers in specialty occupations) was cut from 195,000 to 65,000 in 2003 (Lewin et al., 2007). Companies can gain access to available qualified labour abroad, which is, to some extent, immobile (Dicken, 2007, p. 112). Fourthly, companies have access to superior or complementary knowledge in foreign locations. They may, for example, acquire foreign companies with complementary skills to the company. Roche, Switzerland, for instance, acquired in 2008 the biotech company Piramed, United Kingdom, to gain access to research specialised in oncology with the potential for treating major cancers, such as those of the breast and lung. MNEs may also acquire new knowledge by setting up near universities or competitors to capture and share more easily the best ideas. Finally, companies can also be encouraged by the government to carry out R\&D activities through grants or other incentives.

These several motives have been divided in the literature into two categories: "asset-exploiting activities", which refine and extend existing competencies or technologies created in the home country, and "asset-augmenting activities", which seek to acquire and develop new knowledge (Dunning and Narula, 1995; March, 1991; Florida, 1997; Cantwell and Janne, 1999; Zander, 1999a,b; Frost, 2001; and Ambos and Schlegelmilch, 2008). Assetexploiting activities imply that, in establishing R\&D subsidiaries in foreign locations, MNEs use the existing knowledge of the company created in the home country. In this case, the knowledge is exclusively transferred from the parent company to the subsidiary. The home country is thus the most valuable contributor to the technological advancement of the firms and subsidiaries are the receiving units of knowledge. Asset-augmenting activities entail MNEs being able to experiment with new alternatives in foreign subsidiaries. The knowledge is acquired abroad through inter-firm spillovers or cross-border acquisitions. Technologies are thus developed in subsidiaries with the competences of the host country. In this case, foreign subsidiaries create innovations and may transfer knowledge to the home country. In consequence, the home country becomes a receiving unit of knowledge and is no longer the main contributor to the innovative activities of domestic companies. This new role of foreign R\&D activities needs to be analysed with regard to the consequences for home economies.

\section{Effects on Home Economies}

\section{Knowledge Transfer}

One of the main benefits linked to the internationalisation of domestic firms' $R \& D$ is the acquisition of foreign knowledge. Indeed, the internationalisation of R\&D activities allows MNEs to learn from others and to 
acquire specific knowledge located in the host environment. Once these new competences are integrated within the subsidiary, they should be transferred to the parent company in order to improve the competences of the whole organisation. The home economy can benefit from this dispersion when the knowledge acquired in foreign locations is transferred to the parent company. This issue is important for home countries as they can profit from the dispersion of R\&D activities through the transfer of knowledge from foreign subsidiaries to the parent company ("intra-firm reverse knowledge transfer", see Criscuolo, 2002, and Frost and Zhou, 2005) and then to other domestic companies in the home country ("inter-firm reverse knowledge transfer"). There are thus three possible steps in the transfer of knowledge: 1) from the local environment of the host country to the MNE's subsidiary, 2) from the MNE's subsidiary to the parent company, and 3) from the parent company to the local environment of the country of origin. ${ }^{1}$ In this sense, the country of origin becomes the recipient of new skills. However, "knowledge transfer is a complex phenomenon and, in practice, successful transfer is often not easy to achieve" (Easterby-Smith et al., 2008, p. 677). There are three main reasons for the difficulties of transfer, which are summarised as follows.

First, knowledge is more easily acquired when MNEs are embedded in the host region as knowledge is disseminated more quickly and easily when MNEs have links with suppliers, clients, competitors, research institutions, universities or industry associations (Criscuolo, 2002, p. 3). Because this process of becoming embedded is long and costly, it takes time for firms to acquire new knowledge. Secondly, transfers work better if receivers of knowledge have the required absorptive capacity (OECD, 2005a, p. 38). This means that employees must understand, implement and assess the value of knowledge (Ambos et al., 2006) and, in addition, should be open to new ideas (Inkpen, 2008, p. 88). Furthermore, a gap between the vision of the parent company and the perspective of the subsidiaries can result in conflict or incomprehension (Buckley and Carter, 2004, p. 377). Thirdly, geographical distances create practical obstacles to person-based communication mechanisms, which is the best way to transfer new knowledge, due to its tacit nature (Makela et al. 2007). Indeed, according to Piscitello and Rabbiosi (2007), codified communication (for instance written media) is a much less effective way of transferring new knowledge than personal communication (inter-unit trips and visits, international committees, training involving participants from multiple units), which facilitates the development of interpersonal ties in the MNE. However, personal communication encounters difficulties through differences in the cognitive knowledge, specialization, language, social norms and identities of individuals, as well as the possible unwillingness of participants to reveal what they know and pass their capabilities on to others (Buckley and Carter, 2004, p. 376-7). These differences could decrease with better connections and frequent interactions between individuals. Nevertheless, geographical and temporal distances create practical obstacles to interactions, making it difficult to meet easily.

In consequence, barriers to knowledge transfer exist. One of the strategic challenges of headquarters today lies in the selection and establishment of mechanisms that support and enhance the transfer of knowledge between units (Björkman et al. 2004, and Foss and Pedersen, 2004). Indeed, the sharing of knowledge can become a competitive advantage. For instance, it is obvious that communication on research projects and on units' competences between subsidiaries could avoid duplication of effort and create synergies. Furthermore, given that foreign subsidiaries acquire new knowledge of their host country, which is conducive to global innovation, MNEs must ensure that new insights are disseminated throughout the entire organization.

\section{Loss of Technological Capacity}

The internationalisation of R\&D activities gives rise to concerns, both for MNEs (depleting their proprietary technologies by interacting with foreign partners) and for home countries (loss of technological capacity or the "hollowing out" effect). Firstly, MNEs, and thus their country of origin, given that the key technologies of MNEs are often developed there (Criscuolo et al., 2005), can lose control over their proprietary technologies by interacting with foreign partners and therefore lose a strategic advantage in international markets (OECD, 2005). This stems from the fact that the technologies of MNEs can fall into the hands of competitors abroad (Singh, 2007, p. 767; see also Sanna-Randaccio and Veugelers, 2007). This possibility of increasing the productivity of a

1 In fact, knowledge transfer may take place through MNEs in at least five different forms (e.g. Gupta and Govindarajan 1991; Piscitello and Rabbiosi, 2007): (i) flows from parent company to subsidiaries, (ii) flows from subsidiaries to parent company, (iii) flows from local environment to subsidiary, (iv) flows from subsidiary to local environment, (v) flows to peer subsidiaries. However, with regard to the implications for the home country, the three flows mentioned in the text are the most relevant. 
competitor may involve a tendency to under-invest in R\&D (Audretsch, 1998, p. 20). A second negative effect could arise when the internationalisation of $R \& D$ activities is accompanied by a decreasing role of the home country in the generation of firms' innovations and a potential relocation of home R\&D activities. Decentralising and centralising forces will determine the role of the home country. On the one hand, initial firm-specific technology developed at home is exploited abroad in order to adapt products or processes to local conditions ("asset-exploiting activities"). In this context, core activities are concentrated in home countries and foreign activities enhance the technologies developed at home. In centralising R\&D activities in their home country, MNEs can benefit from economies of scale, facilitate the coordination and the control of R\&D investments, avoid duplication, limit the risk of imitation and the leakage of information, and finally decrease the costs of communication. Besides, according to Narula (2002), companies are embedded in the innovation system of their country of origin and a change of system would be a long and costly process. Therefore, the high costs of integration in innovation systems of host countries, compared to the relatively low marginal costs of keeping the innovation system of the country of origin, creates inertia that makes companies hesitant to internationalise.

On the other hand, domestic R\&D activities are not the sole sources of knowledge that MNEs exploit. They can also gain access to foreign sources of knowledge to complement their $R \& D$ activities at home or to acquire or create new, unique, intangible assets, for example, by gaining access to the ownership advantages enjoyed by firms in that location ("asset-augmenting activities"). Using this strategy, the core of innovative activities may be decentralised and important innovations can be produced abroad. Once the MNE becomes embedded in the host's national system of innovation, marginal costs of expansion there decline and the MNE has motivation to invest there. If the home innovation system has weaknesses and the costs of internationalisation are reduced, a relocation of $\mathrm{R} \& \mathrm{D}$ could take place. Little is known about this potential relocation, despite the fact that some MNEs in some cases invest more abroad than at home. For instance, in 1986, Swiss companies had more laboratories outside their home country than within it (Pearce and Singh, 1991). Furthermore, Novartis moved its R\&D headquarters from Basel to Cambridge, Massachusetts, in 2003. This decision has raised some concerns about relocation of Swiss R\&D activities.

Summing up, a new role of foreign R\&D has emerged in the literature; i.e., the access to foreign sources of innovation. This new trend implies consequences for home countries that need to be assessed. Indeed, the country of origin is no longer the sole source of knowledge for domestic companies, which are influenced by R\&D done abroad. In consequence, domestic companies can increase their competitiveness in acquiring superior knowledge from innovative regions and integrate this knowledge in the home country. However, the internationalisation also means that $R \& D$ could be relocated and innovations imitated. Internationalisation of R\&D thus offers opportunities, as well as threats, to the economic future of home countries. The next section will assess empirically the issue of internationalisation of $R \& D$.

\section{INNOVATION LOCATION OF SWISS MNES}

Patents are frequently used to reflect the innovative performance of countries, regions and firms, as well as other aspects of the dynamics of the innovation process (OECD, 2006a, p. 6). The advantages and disadvantages of using this indicator have been extensively discussed (Griliches, 1990; Cantwell, 1993, 1995; Pavitt, 1988; and Patel and Pavitt, 1991) and most authors tend to conclude that patent statistics can be useful indicators: "In spite of all the difficulties, patents statistics remain a unique source for the analysis of the process of technical change. Nothing else even comes close in the quantity of available data, accessibility, and the potential industrial, organisational, and technological details." (Griliches, 1990, p. 1702) It should be noted, however, that not all inventions are patented and that inventions which are patented are not always innovations. However, patents are a good indicator of the technological production of the firms as they use patents as legal protection for their most valuable innovations (Filippaios et al., 2007, p. 6).

The data used in the present research include patents and patent citations published by the EPO from December 1978 to September 2006. The patents database was constructed by the OECD ("OECD/EPO patent citations database"). The MNEs included in the data set have their headquarters in Switzerland and are the most innovative firms according to patent applications (only firms with a minimum of 20 patent applications published by the EPO between 2004 and 2006 were included in the analysis). A total of 71 firms were investigated, of which 13 
are listed in the Global 2000 of Forbes (2008). High-technology industries represent 41 percent of the firms, as against 42 percent for high-medium technology industries, 13 percent for medium-low technology industries and 4 percent for low technology industries. The ownership and affiliates structure of the firms was elucidated using annual reports and web sites. Some errors may have been introduced by the fact that we do not have the complete ownership data for the full period. Spelling mistakes in firms' names in the database were verified using a manual process. We were able to identify a total of 39,281 patents applied for at the European Patent Office during the period 1978-2006.

\section{Geographical Dispersion}

The extent of Swiss MNEs' innovative activities outside the home country is analysed in this section. Data on patents is an indicator of the level of the global innovative activities of Swiss MNEs as patent records include the name and the address of the inventor(s), as well as the name and address of the applicant(s). Assuming that the address of the inventor coincides with the geographical location of the invention (a measure used by Cantwell, 1992; Le Bas and Sierra, 2002; Patel and Vega, 1999, among others), this information allows us to identify where the technological work underlying the innovation was mainly carried out.

Patents were selected by their applicants (i.e., the multinational firms) and we identified the location of the invention by looking at the inventor's address. Using this information, we were able to identify a total of 96,651 inventors, including 36,918 inventors in Switzerland and 59,733 inventors from 70 different foreign countries. This number of inventors $(96,651)$ exceeds the number of patents $(39,281)$ as some patents have several inventors. In this case, we use a fractional counting method (see OECD, 2006b, Criscuolo, 2002; and Verspagen and Schoenmakers, 2004). For example, if there are $p$ inventors in Germany and $q$ inventors in France for the same patent, Germany is attributed $p /(p+q)$ of the patent and France $q /(p+q)$.

The data in Figure 1 show that there has been a strong increase in the level of internationalisation of Swiss innovative activities. Swiss MNEs' patents generated in foreign subsidiaries amounted to 43.6 percent of the total Swiss MNEs' patents in the 1980s, which rose to 54 percent in the 1990s and to 61.8 percent between 2000 and 2006. These results confirm that Swiss MNEs locate a growing part of their R\&D activities outside the home country. The argument that R\&D activities are centralised in the home country is thus no longer valid according to the patents data. However, Swiss MNEs have not reduced their activities at home and Switzerland remains the country where Swiss MNEs do most of their innovative activities (1,412 inventions were generated in Switzerland in 2005, 736 in Germany, 560 in the US and 207 in France). The internationalization has thus not been accompanied by a reduction of $R \& D$ activities at home.

Figure 1.Trend in the Internationalisation of the R\&D Activities of Swiss MNEs

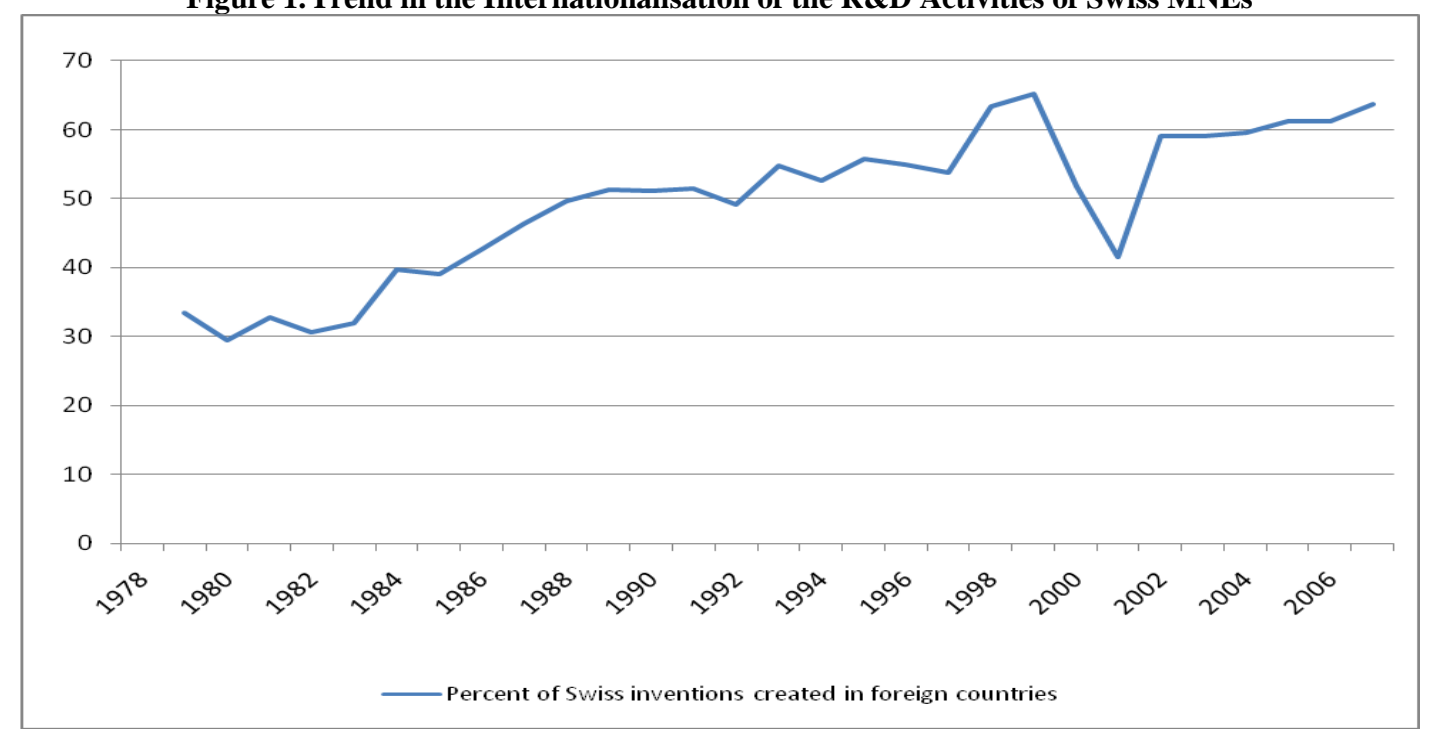


The breakdown by partner country shows that R\&D subsidiaries of Swiss MNEs are concentrated in a few developed countries: 79.3 percent of the inventions realised abroad by Swiss MNEs were invented in Germany, in the US, in France and in the United Kingdom (Table 1). Swiss R\&D in Germany has created 40.7 percent of Swiss MNEs' foreign inventions; the US, 23.2 percent; France, 8.3 percent; and the United Kingdom, 7.1 percent. In consequence, Swiss MNEs perform R\&D activities in innovative countries. For instance, Germany ranked first in the capacity for innovation index of the Global Competitiveness Report 2008-2009 (World Economic Forum, 2008, p. 486); Japan, second; Sweden, fourth; and the US, sixth. Switzerland was in the third place.

Table 1. Location of Swiss MNEs Patents' Inventors, 1978-2006

\begin{tabular}{|l|c|c|c|}
\hline \multicolumn{1}{|c|}{ Country } & Number of inventors & Percent in total inventors & $\begin{array}{c}\text { Percent in total foreign } \\
\text { inventors }\end{array}$ \\
\hline Switzerland & $17,259^{*}$ & $43.9^{* *}$ & - \\
\hline Germany & 8,967 & 22.8 & $40.7 * * *$ \\
\hline United States & 5,118 & 13.0 & 23.2 \\
\hline France & 1,822 & 4.6 & 8.3 \\
\hline United Kingdom & 1,566 & 4.0 & 7.1 \\
\hline Sweden & 1,290 & 3.3 & 3.9 \\
\hline Japan & 753 & 1.9 & 3.3 \\
\hline Italy & 722 & 1.8 & 2.1 \\
\hline Austria & 468 & 1.2 & 6.0 \\
\hline Others & 1,316 & 3.5 & 100.0 \\
\hline Total inventors & 39,281 & 100.0 & \\
\hline Total foreign inventors & 22,022 & & \\
\hline
\end{tabular}

Note: * The number 17,259 means that 17,259 patents filed by Swiss companies protect inventions realised in Switzerland. ** 43.9 percent of total Swiss patents protect inventions created in Switzerland. *** 40.7 percent of Swiss patents created in foreign subsidiaries protect inventions realised in Germany.

\section{Geographical Performance of R\&D Activities}

Patents data have shown that there has been an expansion of R\&D activities undertaken by Swiss MNEs in foreign subsidiaries. However, one of the most important disadvantages of patent indicators is that the value distribution of patents is skewed as many patents have no industrial application, whereas a few are of substantial value (OECD, 2006, p. 7). Thus, patents do not take into account differences in the quality of innovations, unlike patent citations (Criscuolo, 2002, p. 9; Criscuolo and Patel, 2003; and Harhoff et al, 1999).

Most patent applications include a list of citations of earlier patents that capture "prior art". These citations determine the boundaries of a patent's claims of novelty, inventive activity and industrial applicability (OECD b, 2006, p. 38). A range of indicators, based on patent citations, has been developed providing insights into knowledge flows and value of patents. ${ }^{2}$ According to Criscuolo et al. (2002, p. 9), "the assumption is that a reference to a previous patent indicates that the knowledge in the latter patent was in some way useful for developing the new knowledge described in the citing patent." When a patent is cited by an inventor, it is assumed that this patent has had some scientific value to the inventor. In this section, we will identify the patents cited by Swiss MNEs to compare the quality of the foreign technological activities with that of the home country technological activities.

The 39,281 Swiss patents described previously cite 6,620 patents. Suppose a patent $X$ applied for by a Swiss firm cites another patent $\mathrm{Y}$. This patent $\mathrm{Y}$ is a cited patent and patent $\mathrm{X}$ is the citing patent. In case of multiple cited patents, a fractional counting method is used. For example, if a patent cites three different patents A, B, and C, then a fraction (1/3) of the citing patent is assigned to each of the patents A, B and C. With this method, a total of 6,620 citations have been estimated from the 39,281 patents described in the previous section.

\footnotetext{
${ }^{2}$ For a more detailed discussion of patent citation analysis, readers are referred to Jaffe, Trajtenberg and Henderson (1993); Branstetter (2000); Almeida (1996); Frost (2001); Hall, Jaffe and Trajtenberg (2000) among others.
} 
The data in Table 2 show the origin of the inventor(s) applying for the 6,620 patents cited by Swiss MNEs. In the 1980s, the cited patents were mainly for inventions coming from Switzerland (45.4 percent). In other words, during this period, inventions created in Switzerland were of great scientific value for Swiss companies. However, the share of Swiss inventions in the cited patents declined from 45.4 percent in the early 1980s to 24.4 percent in the early 1990s, to 19.7 percent in the 2000s. In 2003-2006, of the patents cited by Swiss MNEs, 21.9 percent of inventions were created in Germany, 19.7 percent in Switzerland, 19.3 percent in Japan and 16.7 percent in the US. It thus appears that R\&D activities in Switzerland, Germany, Japan and the US now have a substantial value for the development of the innovation activities of Swiss MNEs. As a result, Swiss MNEs use different sources of knowledge and a flow of diverse ideas. They give equal weight to scientific inventions whether made in Switzerland, Germany or Japan.

Table 2. Trends in the Geographical Distribution of Patents cited by Swiss MNEs, 1979-2006

\begin{tabular}{|c|c|c|c|c|c|c|c|c|}
\hline & \multicolumn{2}{|c|}{ 1979-1982 } & \multicolumn{2}{|c|}{ 1989-1992 } & \multicolumn{2}{|c|}{ 1999-2002 } & \multicolumn{2}{|c|}{ 2003-2006 } \\
\hline & Country* & $\%$ & Country* & $\%$ & Country* & $\%$ & Country* & $\%$ \\
\hline \multirow{5}{*}{$\begin{array}{l}\text { Origin of } \\
\text { cited patents }\end{array}$} & $\mathrm{CH}$ & 45.4 & $\mathrm{CH}$ & 24.4 & $\mathrm{DE}$ & 23.0 & $\mathrm{DE}$ & $21.9 * *$ \\
\hline & $\mathrm{DE}$ & 18.3 & US & 21.3 & $\mathrm{CH}$ & 19.7 & $\mathrm{CH}$ & 19.7 \\
\hline & US & 14.0 & $\overline{D E}$ & 20.8 & US & 18.1 & JP & 19.3 \\
\hline & GB & 9.7 & $\mathrm{JP}$ & 12.0 & $\mathrm{JP}$ & 16.4 & US & 16.7 \\
\hline & $\mathrm{JP}$ & 6.0 & GB & 6.6 & FR & 7.7 & FR & 4.8 \\
\hline
\end{tabular}

Note: *First five. **21.9 percent of patents cited in 2003-2006 by Swiss firms were invented in Germany.

US: United States; CH: Switzerland; DE: Germany; JP: Japan; GB: United Kingdom; FR: France

\section{Knowledge Sourcing of Foreign R\&D}

Patent citations are also useful in determining the locations in which research subsidiaries source their knowledge. This allows one to consider whether the foreign R\&D activities are asset-augmenting; i.e., creating innovations in the host country, or asset-exploiting; i.e., improving innovations carried out in the country of origin. Foreign subsidiaries citing more inventions created in their environment than in the country of origin are described as asset-augmenting. Conversely, foreign subsidiaries citing more inventions created in the country of origin than in their host country are qualified as asset-exploiting.

In Figure 2, the left circle represents inventions created in the host country of the subsidiary. The right circle represents inventions created in Switzerland. The circle in the middle corresponds to inventions created in the subsidiary in the host country. The arrows identify the transfer of knowledge. The left arrow indicates the extent of transfer from the environment of the subsidiary to the subsidiary. The right arrow indicates the extent of transfer from the country of origin to the foreign subsidiary.

The transfer of knowledge in the host country is greater than the transfer from the country of origin to the subsidiary. Indeed, the citation analysis has shown that subsidiaries conducting R\&D abroad predominantly refer to their host countries rather than their country of origin. On average, 41 percent of patents cited by foreign subsidiaries were created in their host country and 10 percent of inventions cited by foreign subsidiaries were created in Switzerland. For example, subsidiaries of Swiss companies in Germany cite more inventions made in Germany than inventions created in Switzerland. They cite 642 inventions made in Germany (42.5 percent of cited patents) and 157 inventions made in Switzerland (10.4 percent of cited patents). Thus Swiss R\&D in Germany uses mainly German sources of knowledge. The situation is the same for all host countries. For example, 54.2 percent of inventions cited by Swiss subsidiaries in the US were created in the US compared to 7.9 percent in Switzerland.

It can be concluded that foreign $\mathrm{R} \& \mathrm{D}$ is asset-augmenting rather than asset-exploiting and draws on sources of knowledge in their local environment. Consequently, the competitive advantage of Swiss MNEs increasingly stems from subsidiary-specific advantages that emanate from the location of units in multiple knowledge centres. Switzerland is therefore not the main source of knowledge for the global R\&D activities of Swiss MNEs.

In addition, this result implies that the home country is not exclusively a contributor of knowledge, but also a recipient of competences. The data have demonstrated a flow of knowledge from foreign locations to the home 
country. In the sample described above, inventors of Swiss MNEs located in Switzerland have cited foreign locations; i.e., 61.5 percent of the citations listed in patents filed by Swiss MNEs and invented in Switzerland were for inventions created abroad. This could be seen as a sign of the integration of knowledge from foreign locations with that from the home location. However, to be more precise in the analysis of intra-firm reverse technology transfer, we must focus on the cited patents invented in foreign subsidiaries belonging to the MNE. Thus, we use a citation by a headquarters of a patent filed by a foreign subsidiary as the basis for the measure of reverse knowledge transfer (a measure developed by Frost and Zhou, 2005, p. 679). The results show that among the 3,372 patents cited by the headquarters of Swiss MNEs, 127 patents belonged to their own subsidiaries. It could be concluded that there is a knowledge flow from foreign subsidiaries to the parent company in the home country.

Figure 2. Knowledge Sourcing of Foreign R\&D

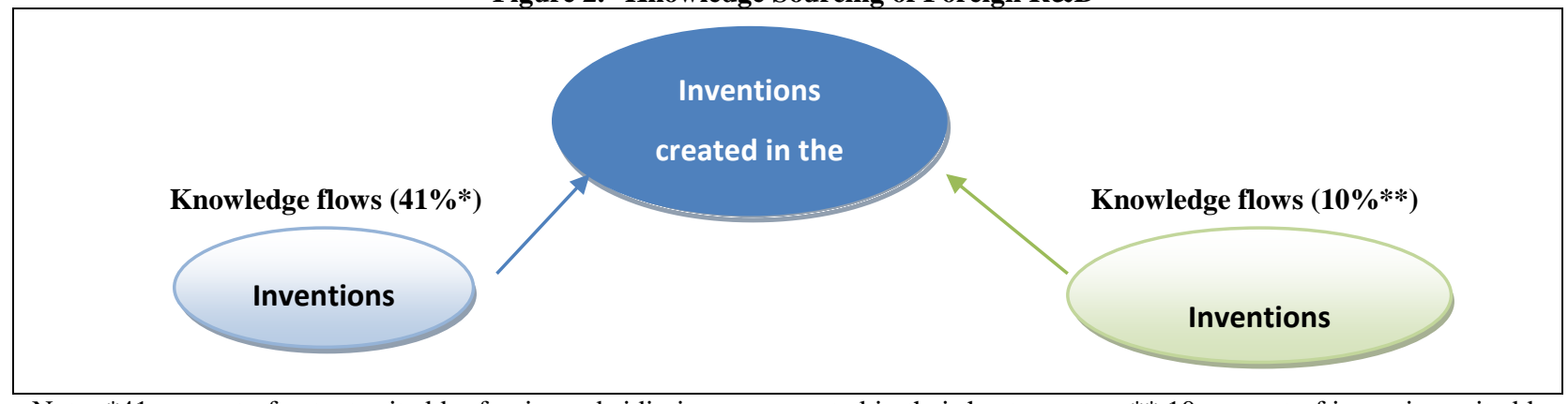

Note: $* 41$ percent of patents cited by foreign subsidiaries were created in their host country. $* * 10$ percent of inventions cited by foreign subsidiaries were created in Switzerland.

\section{MAIN MOTIVATIONS OF SWISS FOREIGN R\&D ACTIVITIES}

The patents analysis is complemented by a questionnaire sent out in May 2008 to the 71 Swiss firms described in the previous section. In July 2008, 35 major firms had responded (response rate of 49.3 percent). Hightechnology industries represented 40 percent of the respondent firms, compared to 37.1 percent representing highmedium technology industries, 11.4 percent for medium-low technology industries and 5.7 percent for low technology industries. The survey is used to explain the motivations of Swiss MNEs conducting R\&D activities in subsidiaries in developed countries, in developing countries and in China.

The data in Table 3 show the factors that lead Swiss MNEs to internationalise their R\&D activities. The strongest driving forces in developed countries are perceived as more important than the strongest driving forces in developing countries and in China. The addition of the degrees of importance confirms that the motives for internationalisation in the developed countries predominate (17.26), followed by China (14.52) and those in developing countries (12.09). This is consistent with the prevalence of developed countries as a destination of Swiss R\&D activities. However, the driving forces in China have the strongest tendencies to increase (addition of 3.74), followed by developing countries (addition of 2.74) and developed countries (addition of 1.77), showing the growing importance of China and developing countries as host locations for R\&D activities.

Supporting local customers and markets is the strongest driving force in developed countries, developing countries and China. The most frequent motivation for foreign R\&D is thus the customisation of existing products and technologies to local market needs, confirming the results of many studies (see Love, 2003; Balcet and Evangelista, 2005; and Rose and Volker, 2005). Indeed, in order to be successful in a specific market, firms need to come up with products that are perfectly adapted and tailored to the needs of the potential customers and to the social and cultural environment in which they live. The best way to do so is partly to develop the products locally. The predominance of this driving force for the internationalisation of Swiss R\&D can be explained by the relatively small domestic market of Switzerland. Swiss companies need to globalise their sales if they want to increase their profit. In consequence, Swiss MNEs set up R\&D units abroad to allow them to enjoy a geographical link between markets and production and to adjust the products or processes to local needs or local conditions. The emergence of Asia as an R\&D location illustrates this motivation. For three decades, China's GDP per capita has risen 
significantly at an approximate average of 8 percent per year over the past two decades (Schwaag Serger, 2006, p. 230). Accordingly, the middle and upper classes have emerged with an increase in purchasing power and wealth (Schwaag Serger, 2006, p. 230). This growth in market size gives Swiss companies an opportunity to sell their products in China. However, Chinese culture, tastes, needs, education and rules are very different from those of Switzerland. Companies must adapt their products, services or processes to the local conditions.

Creating better access to highly qualified labour has the strongest tendency to increase in developed countries and in developing countries. Creating better access to foreign science and technology has the strongest tendency to increase in China (followed closely by the access to highly qualified labour). For instance, Novartis invested in China to enable it to benefit from Chinese traditional knowledge. It collaborated with partners, such as the Chinese Military Academy of Medical Sciences, in order to create Coartem (the brand name for a combination of artemether and lumefantrine) against malaria. ABB also has a R\&D unit in China that jointly conducts research with the Tianjin University in relay protection in the power system. These results confirm that companies are increasingly investing abroad so that they can hire the best talents and be close to universities or centres of research. Indeed, "as more and more sources of potentially relevant knowledge emerge across the globe, companies must establish a presence at an increasing number of locations to access new knowledge and to absorb new research results from foreign universities and competitors into their own organizations" (Kuemmerle, 1997, p. 61). Furthermore, the results confirm the evolving role of overseas R\&D laboratories shown by Asakawa (2001) from being a receiving point for technologies transferred from the parent company to being a development centre for original technologies. According to Asakawa, the pace of this evolution is slower for subsidiaries located in developing countries, but in India and China there is a good possibility that the role of R\&D bases will evolve in a very short time (Asakawa, 2005). The analysis of data on Swiss MNEs shows that the access to talents and to local science and technology has increased in developing countries and in China, with a greater tendency to increase in China (0.58 and 0.59 compared to 0.52 and 0.32 in developing countries) and a higher degree of importance (1.63 and 1.61 in China compared to 1.42 and 1.25 in developing countries). These motives are already strong in developed countries (degree of importance of 2.31 and 2.29) and MNEs do not intend to increase them significantly in the developed countries $(0.44$ and 0.31$)$.

The differences in the cost of factor endowments between countries do not seem to be a predominant driving force. According to our investigation, and contrary to what is commonly assumed, the low level of wages in China is of secondary importance when Swiss companies decide to invest there. This can be explained by the fact that the cost of qualified labour rises in China and in emerging countries as demand for talent increases. The local government incitation was the narrowest motive in all regions. Companies are more likely to take into account the quality of the national innovation system and whether they can benefit from scientific and technological superiority.

Table 3. Motives for the Internationalisation of R\&D by Swiss MNEs in Developed Countries

\begin{tabular}{|l|l|l|l|l|l|l|}
\hline \multicolumn{1}{|c|}{ Motive } & \multicolumn{2}{|c|}{ Developed countries } & \multicolumn{2}{c|}{ Developing countries } & \multicolumn{2}{c|}{ China } \\
\hline & \multicolumn{1}{|c|}{ Imp. } & \multicolumn{1}{|c|}{ Ten. } & \multicolumn{1}{c|}{ Imp. } & Ten. & Imp. & Ten. \\
\hline Supporting local customers and markets & $2.56(1)$ & 0.27 & $2.00(1)$ & 0.38 & $2.27(1)$ & 0.48 \\
\hline Access to highly qualified labour & $2.31(2)$ & 0.44 & $1.42(4)$ & 0.52 & $1.63(4)$ & 0.58 \\
\hline Access to foreign science and technology & $2.29(3)$ & 0.31 & $1.25(6)$ & 0.32 & $1.61(5)$ & 0.59 \\
\hline Supporting local production & $2.17(4)$ & 0.11 & $1.52(2)$ & 0.27 & $1.75(3)$ & 0.40 \\
\hline Being present in a local cluster & $1.86(5)$ & 0.11 & $1.07(8)$ & 0.29 & $1.35(7)$ & 0.38 \\
\hline Local ambitions among subsidiaries & $1.71(6)$ & 0.26 & $1.14(7)$ & 0.29 & $1.33(8)$ & 0.40 \\
\hline Country's regulations & $1.65(7)$ & 0.07 & $1.50(3)$ & 0.20 & $1.85(2)$ & 0.33 \\
\hline Access to cost-effective supply of R\&D workforce & $1.38(8)$ & 0.12 & $1.31(5)$ & 0.30 & $1.60(6)$ & 0.35 \\
\hline Local government incitations & $1.33(9)$ & 0.08 & $0.88(9)$ & 0.17 & $1.13(9)$ & 0.23 \\
\hline Addition & 17.26 & 1.77 & 12.09 & 2.74 & 14.52 & 3.74 \\
\hline Mean & 1.92 & 0.20 & 1.34 & 0.30 & 1.61 & 0.42 \\
\hline
\end{tabular}

Notes: Each company was asked to indicate the relative importance of the motives and driving forces behind the company's internationalisation of R\&D. Column Imp.: Each company was asked to rate the importance of the motive. Scale: no importance $=0,1,2,3,4=$ of major importance. Column Ten.: Each company was asked to give a rating regarding the future tendency. Scale: decreasing $=-1,0,+1=$ increasing. 
The questions asked were quite similar to those in the questionnaire used by Granstrand (1999) in a survey of 24 and 23 large corporations in Japan and Sweden, respectively. Creating access to foreign science and technology was the strongest driving force in Japanese corporations, while foreign acquisitions and the need for local market support were the most important driving forces in Swedish corporations. Since the strongest driving force in Swiss MNEs was supporting local customers and markets, it seems that Swiss MNEs are similar to Swedish MNEs in their R\&D internationalization factors. However, differences between the three groups of countries are small. The access to science and technology becomes significant for the three groups of countries.

\section{CONCLUSION}

The results show that Swiss MNEs perform a high and an increasing share of their R\&D activities abroad. The argument that R\&D activities are centralised in the country of origin is no longer valid for Switzerland. The main foreign locations of R\&D are a few developed countries (Germany, the US, France and the United Kingdom), but MNEs are investing and will continue to invest strongly in China and in Asian countries. Swiss companies primarily engage in foreign $R \& D$ activities to improve their products in accordance with the requirements of the host regions and to access science and technology and local talent. Arbitrations on wage levels lose their impact.

Switzerland profits from this dispersion of R\&D. First, foreign R\&D subsidiaries of Swiss MNEs draw on sources of knowledge from their local environment. In consequence, Swiss MNEs have access to a varied flow of ideas which influence their innovative performance. MNEs acquire the most advanced skills and the best scientists, as well as being able to adjust their products to foreign markets to win market share. Furthermore, the internationalisation of $R \& D$ enables firms to go beyond national constraints. For instance, they can gain access to scientists abroad when the home country has a shortage of highly qualified labour. Secondly, the study has determined that transfers of knowledge between subsidiaries and between subsidiaries and the parent company occur. These transfers are essential in order to avoid duplication of R\&D efforts and to facilitate the dissemination of competences. In addition, one research unit alone is not able to develop competencies in all technological fields. It is thus necessary to share knowledge. Finally, internationalisation of R\&D by Swiss firms has not been accompanied by the closure of centres in Switzerland. Domestic companies still invest strongly in R\&D in Switzerland. Indeed, domestic firms become more competitive through their access to the host country's specific advantages and spend more resources in the country of origin, the basis of their first competitive advantage (Dunning and Gugler, 2008, and Dunning and Lundan, 2008). Fears about the off-shoring of R\&D activities should thus be balanced against the gains resulting from the internationalisation.

These results are of great value for politicians and managers. To benefit from R\&D activities abroad, they must recognise this internationalisation and its potential. Policies should be oriented in the direction of the support of knowledge transfers from foreign countries to the home country. It may, for instance, help domestic actors to adopt innovations abroad, attract foreign talent by adapting the policy on immigration, promote collaborations between domestic and foreign partners, encourage the international mobility of researchers, or support the expansion of domestic research (Guimón, 2009). The policies should also integrate developing and emerging countries in their measures as MNEs invest strongly in R\&D activities in these regions. Knowledge transfer in the home country may also be encouraged by fostering synergies and networks between research institutions, associations, universities and enterprises or by encouraging technology transfer programmes. The results give points for consideration by managers about their R\&D activities, which is the most valuable input for competitive advantages. Managers should select the location of their R\&D activities carefully as "It generally takes a long time (several years) for a new laboratory to become integrated in the local science community and to make use of locally available external effects (Perrino/Tipping 1989) ... thus, the costs of choosing the second best location for an $R \& D$ site are high and often exceed the cost of choosing the second best manufacturing location by a multiple" (Kuemmerle 1996, p. 123). As MNEs increasingly invest abroad to acquire local competences, firms need to follow this trend in order to be competitive. Furthermore, they have to establish mechanisms that support and enhance the transfer of knowledge between units, as knowledge sharing could be a new competitive advantage. 


\section{AUTHOR INFORMATION}

Philippe Gugler, Professor, Director of the Center for Competitiveness, Faculty of Economics and Social Sciences, University of Fribourg, Switzerland. Contact: Bd de Perolles 90, 1700 Fribourg, Switzerland.

Julie Michel, Research Assistant, Center for Competitiveness, Faculty of Economics and Social Sciences, University of Fribourg, Switzerland.

\section{REFERENCES}

1. Aghion, P. and P. Howitt (1992). "A model of growth through creative destruction". Econometrica 60, pp. 323-51.

2. Ambos, T., Ambos, B. and B. B. Schlegelmilch (2006). "Learning from foreign subsidiaries: An empirical investigation of headquarters' benefits from reverse knowledge transfers". International Business Review 15(3), pp. 294-312.

3. Ambos, B. and B. B. Schlegelmilch (2008). "Innovation in multinational firms: Does cultural fit enhance performance". Management International Review 48(2), pp. 189-206.

4. Asakawa, K. (2001). "Organizational tension in international R\&D management: the case of Japanese firms". Research Policy 30(5), pp. 735-757.

5. $\quad$ Asakawa, K. (2005). "Accelerating R\&D Investments into India and China". Research Institute of Economy, Trade and Industry, Japan.

6. Audretsch, D. B. (1998). "Agglomeration and the location of innovative activity". Oxford Review of Economic Policy 14, pp. 19-29.

7. Bjorkman, I., Barner-Rasmussen, W. and L. LI (2004). "Managing knowledge transfer in MNCs: the impact of headquarters control mechanisms". Journal of International Business Studies 35(5), pp. 443-455.

8. $\quad$ Booz \& Company (2008). "Beyond Borders: The Global Innovation 1000". Strategy+Business, Issue 53.

9. Branstetter, L (2000). "Is Foreign direct investment a channel of knowledge spillovers? Evidence from Japan's FDI in the United States". NBER Working Papers 8015, National Bureau of Economic Research, Inc.

10. Buckley, P. J. and J. M. Carter (2004). "A formal analysis of knowledge combination in multinational enterprises". Journal of International Business Studies, 35(5), pp. 371-384.

11. Cantwell, J. (1992). "The internationalisation of technological activity and its implications for competitiveness". in O. Granstrand, L. Håkanson and S. Sjölander (eds.). The Internationalisation of R\&D and Technology. Chichester: John Wiley, pp. 75-95.

12. Cantwell, J. (1993). "Corporate technological specialisation in international industries". In CASSON, M. C. and J. Creedy (eds). Economic Inequality and Industrial Concentration. Aldershot: Edward Elgar, pp. 216232.

13. Cantwell, J. (1995). "The globalisation of technology: what remains of the product cycle model?" Cambridge Journal of Economics, 19, pp. 155-174.

14. Cantwell, J. and O. Janne (1999). "Technological globalisation and innovative centers: the role of corporate technological leadership and locational hierarchy". Research Policy, 28, pp. 119-144.

15. Cantwell, J., Glac, K. and R. Harding (2004). "The internationalization of R\&D - the Swiss case“. Management International Review, 44(3), 2004, pp. 57-82.

16. Caves, E. R. (1996). Multinational enterprise and economic analysis, Second edition, Cambridge University Press.

17. Cnuced (2005). Transnational Corporations and the Internationalization of R\&D, World Investment Report. New York and Geneva: United Nations.

18. Criscuolo P. (2004). R\&D Internationalisation and Knowledge Transfer: Impact on MNEs and their Home Countries. Maastricht Economic Research Institute on Innovation and Technology.

19. Criscuolo, P. (2002). "Reverse Technology Transfer: A Patent Citation Analysis of the European Chemical and Pharmaceutical sectors," Research Memoranda 036, Maastricht : MERIT, Maastricht Economic Research Institute on Innovation and Technology.

20. Criscuolo, P. and Patel, P. (2003). "Large Firms and Internationalisation of R\&D: 'Hollowing out' of National Technological Capacity?". SETI Workshop, Rome. 
21. Criscuolo P., Narula, R. and B. Verspagen (2005). "Role of home and host country innovation systems in R\&D internationalisation: a patent citation analysis“. Economics of Innovation and New Technology 14 (5), pp. 417-433.

22. Dicken, P. (2007). Global Shift. Mapping the Changing Contours of the World Economy. London: SAGE Publications.

23. Dunning, J. H. (1993). Multinational Enterprises and the Global Economy. Wokingham: Addison-Wesley Publishing Company.

24. Dunning, J. H. and S. M. Lundan (2008). Multinational Enterprises and the Global Economy. Cheltenham: Edward Elgar.

25. Dunning, J. H. (1977). "Trade, location of economic activity and the MNE: A search for an eclectic approach“. in Ohlin, B., Hesselborn, P.O. and Wijkman, P.M. (eds), The International Allocation of Economic Activity, London: Macmillan.

26. Dunning, J. H. (1988). "The eclectic paradigm of international production: A restatement and some possible extensions“. Journal of International Business Studies 19 (1), pp. 1-31.

27. Dunning, J. H. (2000). "The eclectic paradigm as an envelope for economic and business theories of MNE activity". International Business Review 9, pp. 163-190.

28. Dunning, J. H. (2001). "The eclectic (OLI) paradigm of international production: Past, present and future“. International Journal of the Economics of Business 8 (2), pp. 173-190.

29. Dunning, J. H. and R. Narula (1995). "The R\&D Activities of Foreign Firms in the US". International Studies in Management and Organisation, 25, pp. 39-73.

30. Dunning, J.H. and P. Gugler (2008). Foreign Direct Investment, Location and Competitiveness, Elsevier, Oxford.

31. Dunning, J.H. and S. Lundan (2008). Multinational Enterprises and the Global Economy, Cheltenham: Edward Elgar.

32. Easterby-Smith, M., Lyles, M. A. and E. W. K. Tsang (2008). "Inter-organizational knowledge transfer: current themes and future prospects". Journal of Management Studies 45(4), pp. 677-690.

33. Filippaios, F., Rama, R., Pearce, R., and M. Papanastassiou (2007). "The strategic technological internationalisation of the world's 100 largest food and beverages multinationals". Conference: Four decades of International Business at Reading: Looking to the Future, University of Reading Business School, Centre for International Business and Strategy, Reading, April, 16-17.

34. Florida, R. (1997). "The globalization of R\&D: results of a survey of foreign-affiliated R\&D laboratories in the USA". Research Policy, 26, pp. 85-103.

35. Forbes (2008). The World's Leading Companies, http://www.forbes.com

36. Foss, N. J. and T. Pedersen (2004). "Organizing knowledge processes in the multinational corporation: an introduction". Journal of International Business Studies 35(5), pp. 340-349.

37. Frost, T. (2001). "The geographic sources of foreign subsidiaries' innovations“. Strategic Management Journal 22, pp. 101-123.

38. Frost, T. and C. Zhou (2005). "R\&D co-practice and 'reverse' knowledge integration in multinational firms“. Journal of International Business Studies, 36(6), pp. 676-687.

39. Grandstrand, O (1999). Internationalization of corporate R\&D: a study of Japanese and Swedish corporations". Research Policy, 28(2-3), pp. 275-302.

40. Griliches, Z. (1990). "Patent statistics as economic indicators: A survey". Journal of Economic Literature, American Economic Association, 28 (4), pp. 1661-1707.

41. Guimon, J. (2009). "European policies to benefit from the globalization of corporate R\&D". IB Conference 2009, University of Henley Business School, Reading, United Kingdom.

42. Harhoff, D., Narin, F., Scherer, F. M., and Vopel, K. (1999). "Citation frequency and the value of patented innovation". The Review of Economics and Statistics, MIT Press, 81 (3), pp. 511-515.

43. Hegde, D. and D. Hicks (2008). "The maturation of global corporate R\&D: Evidence from the activity of U.S. foreign subsidiaries". Research Policy 37 (3), pp. 390-406.

44. Inkpen, A. C. (2008). "Managing knowledge transfer in international alliances". Thunderbird International Business Review 50(2), pp. 77-90.

45. Jaffee, A. B., Trajtenberg, M. and R. Henderson (1993). "Geographic localization of knowledge spillovers as evidenced by patent citations“. The Quarterly Journal of Economics, 108 (3), pp. 577-598. 
46. Kotabe, M., Dunlap-Hinkler, D., Parente, R. and Mishra, H. A. (2007). "Determinants of cross-national knowledge transfer and its effect on firm innovation". Journal of International Business Studies 38 (2), pp. 259-282.

47. Kuemmerle, W. (1997). "Building effective R\&D capabilities abroad". Harvard Business Review, MarchApril.

48. Kuemmerle, W. (1999). "The drivers of foreign direct investment into R\&D : An empirical investigation". Journal of International Business Studies, 30 (1), pp. 1-24.

49. Le Bas, C. and C. Sierra (2002). "Location versus country advantages' in R\&D activities: some further results on multinationals' locational strategies". Research Policy, 31, pp. 589-609.

50. Lewin, A.Y., Massini, S. and C. Peeters (2007). "From offshoring to globalization of human capital and innovation". European International Business Academy 2007, Catania, Italia.

51. Lichtenberg, F. R. (1992). "R\&D investment and international productivity differences". NBER Working Paper N. 4161.

52. Makela, K., Kalla, H. K. and R. Piekkari (2007). "Interpersonal similarity as a driver of knowledge sharing within multinational corporations". International Business Review 16 (1), pp. 1-22.

53. March, J. G. (1991). "Exploration and exploitation in organizational learning." Organization Science 2, pp. 71-87.

54. Narula, R. (2002). "Innovation systems and 'inertia' in R\&D location: Norwegian firms and the role of systemic lock-in". Research Policy 31, pp. 795-816.

55. OECD (2005). Internationalisation of R\&D: Trends, issues and implications for S\&T policies.

56. OECD (2006a). "Global Overview of Innovative Activities from the Patent Indicators Perspective". STI Working Paper 2006/3, May.

57. OECD (2006b). Compendium of Patent Statistics 2006.

58. OECD (2007a). Science, Technology and Industry Scoreboard 2007.

59. OECD (2007b). AFA database.

60. OECD (2008a). "Recent Trends in the Internationalisation of R\&D in the Enterprise Sector". Working Party on Statistics.

61. OECD (2008b). Science and Technology Statistics - Main Science and Technology Indicators. Vol 2008 release 02 .

62. Patel, P. and K. Pavitt (1999). "Global corporations and national systems of innovation: Who dominates whom?". In Archibugi, D., Howells, J., and Michie, J. (1999). Innovation Policy in a Global Economy. Cambridge: Cambridge University Press.

63. Patel, P. and M. Vega (1999). "Patterns of internationalization of corporate technology: Location vs. home country advantages". Research Policy 25, pp. 1059-1079.

64. Patel, P. and K. Pavitt. (1991). "Large firms in the production of the world's technology: An important case of "non-globalisation". Journal of International Business Studies 22 (1), pp. 1-21.

65. Pavitt, K. (1988). "Uses and abuses of patent statistics". In Van Raan, A. (ed.). Handbook of Quantitative Studies of Science and Technology. Amsterdam: North Holland, pp. 504-536.

66. Pearce, R. and Singh, S. (1991). Globalizing Research and Development, London: McMillan.

67. Piscitello, L. and L. Rabbiosi (2007). "The impact of knowledge transfer on MNEs' parent companies. Evidence from the Italian case". In Piscitello, L. and G. Santangelo (eds.). Do Multinationals Feed Local Development and Growth?. International Business and Management Series, Elsevier, pp. 169-194.

68. Romer, P. (1990). "Endogenous technological change". Journal of Political Economy 98, pp. 71-102.

69. Rugman, A. and C. H. Oh (2008). "Friedman's follies: Insights on the globalization/regionalization debate". Business and Politics 10(2).

70. Sanna-Randaccio, S. and R. Veugelers (2007). "Multinational knowledge spillovers with decentralised R\&D: a game-theoretic approach". Journal of International Business Studies 38, pp. 47-63.

71. Schwaag Serger, S. (2006). "China: From Shop floor to knowledge factory?" in KARLSSON, M. (ed.). The Internationalization of Corporate $R \& D$. itps, Swedish Institute for Growth Policy Studies.

72. Singh, J. (2007). "Asymmetry of knowledge spillovers between MNCs and host country firms". Journal of International Business Studies 38, pp. 764-786.

73. Swiss Federal Statistical Office, $R-D$ dans l'économie privée en Suisse en 2004. Premiers résultats, 2005.

74. Swiss National Bank (2007). Swiss Balance of Payments, Zurich.

75. Trajtenberg, M. (1990). Economic analysis of product innovation. Cambridge: Cambridge University Press. 
76. UNCTAD (2007). Transnational Corporations, Extractive Industries and Development. World Investment Report 2007. New York and Geneva: United Nations.

77. UNCTAD (2008). Transnational Corporations and the Infrastructure Challenge. World Investment Report 2008. New York and Geneva: United Nations.

78. United States Department of Commerce, United States Bureau of Economic Analysis (2008). Survey of U.S. Direct Investment Abroad, www.bea.gov/bea

79. Van Pottelsberghe De La Potterie, B. and F. Lichtenberg (2001). "Does foreign direct investment transfer technology across borders?". The Review of Economics and Statistics, 83 (3), pp. 490-497.

80. Vernon, R. (1966). "International investment and international trade in the product life cycle". Quarterly Journal of Economics, 80(2), pp.190-207.

81. Verspagen, B. and Schoenmakers, W. (2004). "The spatial dimension of patenting by multinational firms in Europe". Journal of Economic Geography, 4 (1), pp. 23-42.

82. World Economic Forum (2008). The Global Competitiveness Report 2008-2009. Geneva, Switzerland.

83. Zander, I. (1999a). "Whereto the multinational? The evolution of technological capabilities in the multinational network". International Business Review 8 (3), pp. 261-291.

84. Zander, I. (1999b). "How do you mean 'global'? An empirical investigation of innovation networks in multinational corporations". Research Policy 28, pp. 195-213. 
NOTES 